Отримано: 17 грудня 2019 р.

Прорецензовано: 08 січня 2020 р.

Прийнято до друку: 08 січня 2020 р.

e-mail: arin9474@ukr.net

DOI: $10.25264 / 2415-7384-2020-10-4-8$
Astremska I. V. Influence of self-attitude and attitude to others on the success of representatives of professions "person-person" type. Наукові записки Національного університету «Острозька академія». Серія «Психологія» : науковий журнал. Острог : Вид-во НаУОА, січень 2020. № 10. С. 4-8.

\title{
INFLUENCE OF SELF-ATTITUDE AND ATTITUDE TO OTHERS ON THE SUCCESS OF REPRESENTATIVES OF PROFESSIONS "PERSON-PERSON" TYPE
}

The article considers the categories of self-attitude and attitude to others as specific for representatives of the professions of "person-person" type, because the subject of their professional activity is direct interpersonal interaction. In a professional environment, a person learns certain "behavioral patterns" typical of representatives of a particular profession and related to the specifics of the activity performed. The attitude to people around is determined by the framework of these patterns, therefore, representatives of each particular profession are characterized by specific self-attitude and have characteristic features of their attitude to others.

By means of the factor analysis steady complexes of variables are revealed that allow to describe five main types of interrelation of self-attitude and the attitude to others: 1) positive self-attitude at the protective-negative attitude to others. This factor combines the characteristics of timid, insecure people who seek to avoid a hurtful relationship with others; 2) positive self-attitude and selective attitude to others. Representatives of this group are characterized by the ability to effectively manage their own emotions and experiences. Assessment of others is based mainly on external criteria. The sphere of individual psychological characteristics is ignored, because the area of close interaction with other people does not seem particularly significant; 3) conscious positive and indulgently-negative attitude to others. These are self-confident, strong people for whom others are not of particular interest; 4) unconscious positively-inflated self-attitude with a selective attitude to others, which is determined by the level of self-favor. Respondents are not characterized by a tendency to deep reflection, they are quite satisfied with themselves, and their attitude to others is selective: positive to those who treat them favorably and negatively to others; 5) consciously critical self-attitude with a positive attitude to others. These are people who are characterized by a tendency to self-reflection of themselves and doubts about their "I". When the attitude to others is more positive, a person is inclined to better assess others and experiences less sense of superiority.

Three types with a specific combination of self-attitude and attitude to others who experience a "leading" feeling are identified and described: 1) self-esteem, 2) autosympathy, and 3) self-humiliation. Each of the groups has a specific combination of self-attitude and attitude to others, which leaves an imprint on all spheres and areas of life. Especially significant is the impact of this relationship on professional success. The most optimal in this sense will be a combination of positive self-attitude and positive attitude to others, characteristic of the second group of subjects. This is the main criterion for the professional success of professions such as "person-person".

Keywords: self-attitude, self-concept, attitude to others, profession type «person-person», professional success.

\section{Астремська Ірина Володимирівна,}

кандидат психологічних наук, доцент кафедри психологіі

Чорноморського начіонального університету ім. Петра Могили

\section{ВПЛИВ САМОСТАВЛЕННЯ ТА СТАВЛЕННЯ ДО ІНШИХ НА УСПШШНІСТЬ ПРЕДСТАВНИКІВ ПРОФЕСІЙ ТИПУ «ЛЮДИНА-ЛЮДИНА»}

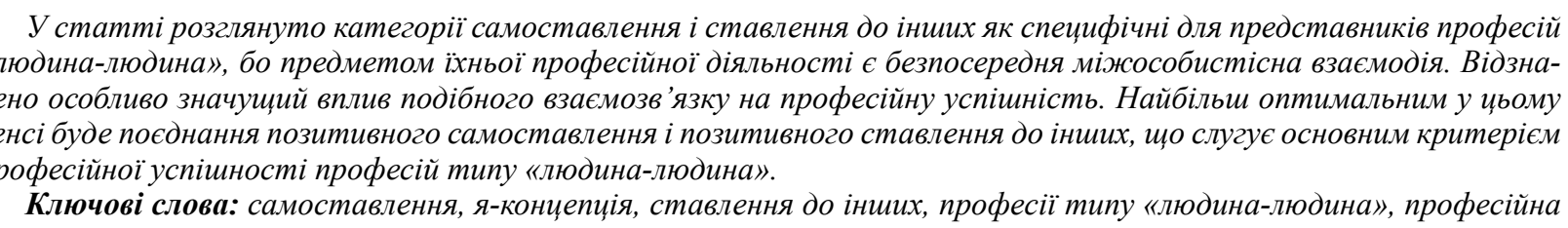
успішність.

Problem statement. The professional activity of a person is also capable of influencing the sphere of his relations, because it is the realization of a basic social need. In the context of fulfilling professional functions, a comparison is made with colleagues, an assessment of oneself based on one's own competence, effectiveness, and success.

It is in professional activity, which is socially significant, that the space of approval or adjustment of selfesteem is formed. 
In the professional environment, a person learns certain "behavioral patterns", typical for representatives of a particular profession, associated with the specifics of the activity performed. Attitude to the surrounding people is also determined by the framework of these patterns. Therefore, representatives of each particular profession are characterized by a specific self-attitude and have characteristic features of attitude to others [6].

Categories of a person's self-relationship and his relationship to others affect all spheres of life: family, industrial, domestic relations. The interconnection of these parameters is not only able to determine the specifics of the interpersonal interaction of the individual, but also have a significant impact on the quality of professional activity and the level of specialist's self-realization.

This is especially true of professions such as «person-person», as the subject of work here are directly interpersonal relationships.

In professional activity, a wide space opens up for the manifestation of self-esteem, its deepening, and adaptation. The degree of self-acceptance of a person, the level of his self-esteem, the measure of positivity of the self-concept affect the nature of his attitude to others and contribute to the success of his professional activity.

In this connection, we decided to consider the issue of the influence of self-attitude and attitude to others on the professional activity of a person at the theoretical and practical levels.

The urgency of the problem is enhanced when it comes to issues of the qualities of professionalism in the new socio-economic conditions and new systems of professional education, as well as the study of personality processes associated with the problem of the formation of professional self-development.

Analysis of recent research and publications. The topic of self-attitude in psychology has been studied quite actively. I. Kohn, N. V. Kazarinova, V. N. Kunitsyna, V. M. Pogolsha, K. Rogers, R. Wiley, S. Gordon define self-attitude as a holistic assessment of a person's «I», as acceptance or non-acceptance of himself $[9,10,21]$.

Another group of researchers studied self-attitude through separate aspects. So V. V. Stolin and S. R. Pantileev argued that the self-attitude of a person is revealed through self-awareness and internal conflict, in which his own personality traits and values are manifested $[16,18,19]$. The problem of social roles and the related problem of self-relationship were investigated by K.V. Muravieva, E. S. Schilstein, J. Mead, J. L. Moreno, and E. Berne [14]. I. N. Semenov and I. A. Repetskii considered that self-attitude should be studied through self-determination and self-realization of personality. [17].

A. N. Leontev connects self-attitude with human motives [11]. N.V. Chudovoi belongs to the idea of studying self-attitude in connection with the mythological identification of the individual. Today, self-understanding is understood as an integral personal characteristic that provides motivation for behavior and activity that contributes to the full development of the individual, to a change in his position in society. Based on the ideas of B.G. Ananiev, L.I. Bozhovich, A.V. Mudrik, N. I. Sardzhveladze, V.V. Stolin, S. L. Rubinstein's self-attitude is considered as the most important element of the entire internal structure of the personality.

The problem of attitude to others was developed by A.V. Andreeva, E.V. Andrienko, A. A. Bodalev, I..L. Kolomenskii, D. Myers, A.V. Morozo, V.N. Miasishchev [2, 3, 4, 8, 12, 13, 15]. I. V. Aleksandrova investigated the relationship of self-attitude and attitudes to others [1]. The study of self-attitude, attitude to others and professional activities belong to the work of O.V. Gorbunov, L.V. Filippova, A.A. Derkach, A.A. Chekalina, R. Wiley $[5,6,20,21]$.

Individual features of a person's self-attitude have a significant impact on the attitude to professional activity and the success of self-realization as a professional.

In professions such as "person - person" it should be noted that there are certain requirements for the personality of a specialist. Such a criterion as a positive attitude towards others is an important characteristic included in the list of requirements. The manifestation of positive feelings and emotions when communicating with people is a necessary condition for successful professional self-realization. A positive attitude towards oneself is no less significant, it is projected onto all spheres of a person's life, therefore it is also a factor determining his professional success.

M. E. Zelenova was engaged in the study of the peculiarities of the relationship of self-relationship and attitude to others on the example of the teacher's activities. She points out that the features of teacher perception of students and their self-perception are always associated with the effectiveness of the educational process. The author claims that there is a connection between the teacher's self-perception, his self-confidence and the effectiveness of pedagogical activity [7].

The study found that teachers with a high degree of self-acceptance have a greater ability to influence the self-concept and success in teaching students. When comparing teachers' self-assessments and grades given to students, it was found that the difference between them for successful teachers is less than for unsuccessful ones. In addition, a comparison was made of the ratings «my students» and «ideal students». It was revealed that successful teachers as a whole evaluate ideal students as real, that is, they tend to accept their students as they are. The idea of unsuccessful teachers about their students is about 1.5 times lower than the idea of ideal students. 
The objectives and tasks of the study are to theoretically substantiate and empirically check the peculiarities of the influence of self-attitude and attitude to others on the success of professional activity.

Statement of the main material. In the course of our work, we investigated the characteristics of the sphere of relations among managers. That is, the representatives of the profession, which also belongs to the category of «man - man». We suggested that the success and effectiveness of the manager's work also depends on such indicators as the measures taken to take them - non-acceptance of themselves, the degree of self-esteem and selfsympathy, the level and adequacy of self-esteem. At the same time, their attitude to others is important.

The empirical research tasks were provided with a set of methodological procedures: the method of «Selfattitude» by S. R. Pantileev, the method of diagnosing interpersonal relationships T. Leary, the method of «Unfinished sentences» (Sachs-Levy). The sample consisted of a group of managers in the amount of 60 people, aged 22 to 48 years.

We have identified stable sets of variables that allow us to describe the main types of relationship between self-attitude and attitude to others in respondents using the mathematical statistical procedure of factor analysis. Factorization by the method of principal components was subjected to a matrix including indicators obtained as a result of the application of a full set of techniques.

The first factor combined the characteristics of timid, insecure people who seek to avoid hurting relationships with others. Their self-attitude is not positive, the relation to others is protective-negative.

Respondents in this group are not sure that their character, activity, actions - everything related to their personality, can cause others to be interested and positive emotions. They consider themselves selfish, stubborn, and capable of aggression and an authoritarian style of communication. At the same time, they understand that they are dependent, suspicious and subordinate. They are characterized by a tendency to deep self-reflection. They carry out an assessment of their «I» through their own interests and hobbies, without taking into account the scope of social roles. Therefore, their own inner world is more significant for them than interaction with other people.

Between such people and their environment is misunderstanding and alienation, they tend to be aloof from everyone.

The second factor combined the characteristics of calm, confident, introverted people who have a positive self-attitude and selective attitude to others.

Respondents in this group have the ability to lead themselves. They perceive their «I» as a kind of inner core, organizing their own personality, activities, behavior, communication, etc. For everything that happens in their lives, they take responsibility only for themselves. Their inner motivations and goals are grounded and consistent. For representatives of this group is characterized by the ability to effectively manage their own emotions and experiences.

Assessment of others is mainly based on external criteria, not taking into account the scope of individual psychological characteristics, as the area of close interaction with other people is not particularly significant.

The third factor combined the signs characterizing self-confident, strong people who have a positive, accepting self-attitude and condescending-negative attitude to others.

Representatives of this group have a fairly conscious self-attitude. They have a certain internal honesty, necessary for the recognition of some of their own qualities (negative from the point of view of everyday morality). At the same time, respondents are self-confident, consider themselves independent, reliable, worthy of self-esteem and respect from others. They are characterized by a sense of self-worth (the characteristics of their spirituality, morality, inner world, etc., have a positive emotional color).

The self-attitude of the representatives of this group is based on the assessment of themselves primarily on external criteria, as well as on the results of their own activities (through Hobbies, interests, inclinations). They do not see themselves as performers of social roles, this area is not too important for them. Although respondents are rated as extroverted (sociable, highly active, impulsive).

The general background of their attitude to other people can be regarded as negative. The surrounding people are not of particular interest to representatives of this group; even the external characteristics of others are not significant, despite the fact that evaluating oneself is based on these criteria.

The fourth factor combined the characteristics of respondents who do not bother to think deeply. They are quite satisfied with themselves; their attitude to others is selective: positive to those who treat them favorably and negatively to others.

Such people have no capacity for self-leadership. They do not consider themselves responsible for events occurring in their own lives, do not tend to look for the causes of actions, results and their own personal characteristics in themselves and believe in the subjection of their «I» to external circumstances. A characteristic feature of the persons of the described group is low self-regulation and inability to control themselves and their emotions.

Such persons do not experience negative emotions to their «I», their own mistakes and shortcomings are not put to themselves. Self-assessment is carried out exclusively on external characteristics. 
Assessment of others is also based on external criteria, without taking into account their individual psychological characteristics. The attitude of representatives of the described group to others can be regarded as consumer-people are mostly perceived as subordinate and altruistic, not capable of authoritarian interaction, which suits them perfectly.

The fifth factor combined the characteristics of people who are prone to deep self-reflection and doubts about their «I» and have a positive attitude to others.

The personalities of the type described are characterized by a tendency to deep self-reflection. Often there are internal conflicts, the result of which may be bursts of negative self-attitude and negative emotions in your address. The respondents of this group readily put their blunders and failures, their own shortcomings to blame.

So, the more positive the attitude to others, that the less the tendency to elevate oneself above others and evaluate better. That is, with a change in attitude to others from negative to positive, a decrease in the degree of concentration on one's own uniqueness, special value, and a change in self-attitude from positive - fully accepting - to negative - self-humiliation. In our opinion, the representatives of the second group can be noted as the most harmonious type of interconnection of self-attitude and attitude to others.

Based on the correlation study, it was found that there is a relationship between the parameters of self-attitude and attitude to others in this sample. The main factors of the modality of the «Self-attitude» methodology were taken as the basis S. R. Pantileev, which allowed us to distinguish several groups of subjects.

The first included respondents with self-esteem. By self-esteem, we mean the ability to open self-relationship, that is, the presence of a certain internal honesty and courage to recognize some of our own qualities, which are not always interpreted as positive and desirable, but are inherent in almost all people, although they are far from universally recognized.

Positively colored reflected self-attitude is the confidence of the subject that his personality, character and activity can cause only positive feelings from others, sympathy, understanding, recognition, support, etc. People with self-esteem are characterized by complete self-acceptance-agreement with their internal impulses, acceptance of themselves. They are characterized by a sense of self-worth.

Persons in this group assess themselves as energetic, competent, authoritative leaders, successful in business, not afraid to be misunderstood or condemned. Each of the representatives of the described category feels like a strong personality.

As for the attitude to others that is characteristic of the people in the described group, we note that when evaluating others, external criteria are absolutely not taken into account. People around are generally perceived as weaker than the representatives of this group themselves, not prone to hostility, exactingness, harshness and aggression.

The second group consisted of subjects with autosympathy. By autosympathy we mean a sense of self-worth and, at the same time, the supposed value of one's «I» for others. Positive emotional coloring of self-assessment according to internal criteria: spirituality, ability to evoke deep, worthy feelings in others, wealth of the inner world, etc.

There are sympathy for oneself, agreement with internal motives, self-acceptance, with all its shortcomings, endorsement of one's own plans and desires, friendly, with a touch of complacency, attitude towards oneself, unwillingness to change, up to the denial of the possibility of developing one's «I» even for the better.

During the study, one feature was identified that characterizes this sample: there is a tendency toward a decrease in autosympathy with increasing age of the respondents.

People who experience a sense of autosympathy consider themselves confident, independent and reliable, possessing strong-willed qualities, which, in their opinion, is the subject of respect from others.

They feel the strength of their «I», have social courage, representatives of this category, as a rule, are highly active, sociable and impulsive and do not have internal tension. They take responsibility for everything that happens in their own lives.

People are perceived by representatives of the type described mainly as soft, delicate, capable of showing compassion, care and affection, able to cheer and calm, disinterested, which is regarded as weakness. Moreover, the individual psychological characteristics of others are not significant for the representatives of this group and are not taken into account when evaluating them.

The third group consisted of respondents who feel a sense of self-humiliation. Self-humiliation is the presence of internal conflicts, doubts, disagreement with oneself. There are constant dissatisfaction with the current situation, the result of which is increased anxiety, a tendency to depression and frustration of leading needs. This also includes the tendency to excessive self-reflection. There are hypertrophic willingness to blame, failures, faults, internal tension and low self-esteem of the individual.

As a result of the study, a tendency was found to decrease the level of internal conflict and self-abasement with increasing age of the subjects.

Persons experiencing a sense of self-humiliation are not able to at least somehow adequately assess their own personality. They are unsure of themselves and, as a rule, are affected by inferiority complexes. Their selfattitude is ambivalent. Attitude to others cannot be assessed as clearly differentiated. 
Conclusions. Thus, through a correlation study, we were able to identify the existence of a relationship between self-attitude and attitude to others in different types of subjects. Each of the groups has a specific combination of self-attitude and attitude to others, which leaves its mark on all spheres and areas of life.

Especially significant is the impact of such a relationship on professional success. The most optimal in this sense will be a combination of positive self-attitude and a positive attitude to others, characteristic of the second group of subjects, which will be the main criterion for the professional success of professions such as "person - person".

\section{References}

1. Александрова Ю. В. Взаимосвязь отношения к Другому и самоотношения взрослого человека. Мир психологии. 1999. №2. С. 38-44.

2. Андреева А. В. Социальная психология. Москва: Аспект Пресс, 2001. 412 с.

3. Андриенко Е. В. Социальная психология. Москва: Академия, 2001. 321 с.

4. Бодалев А. А. Восприятие и понимание человека человеком. Москва: Издательство МГУ, 1982. 298 с.

5. Горбунова О. В., Филиппова Л. В. Самоотношение как показатель субъектной включенности студентов в профессионально - образовательную деятельность. Мир психологии. 2005. №3 (43). С. 67-74.

6. Деркач А. А. Самооценка как структурообразующая процесса акмеологического развития. Мир психологии. 2005. №3 (43). С. 139-146.

7. Зеленова М. Е. Особенности самовосприятия и восприятия своих учеников учителем начальных классов с разным типом педагогического взаимодействия. Психологическая наука и образование. Москва: Институт психологии РАН, 1999. №1. С. 5-10.

8. Коломенский Я. Л. Психология взаимоотношений в малых группах. Минск: Тетра Системс, 1976. 171 с.

9. Кон И. С. Открытие «Я». Москва: Политиздат, 1978. 367 с. (Серия: Над чем работают, о чем спорят философы).

10. Куницына В. Н., Погольша В. М. Межличностное общение. СПб.: Питер, 2002. 544 с.

11. Леонтьев А. Н. Избранные психологические произведения: в 2 т. Москва: Педагогика, 1983. Т. 2. 392 с.

12. Майерс Д. Социальная психология / перев. с англ. СПб.: Изд-во «Питер», 1997. 688 с.

13. Морозов А. В. Психология влияния. СПб.: Издательство «Питер», 2000. 512 с.

14. Муравьева К. В., Шильштейн Е. С. О ролевом компоненте Я-концепции. Вестник МГУ. Серія 14. Психология. 2000. №1. С. 32-38.

15. Мясищев В. Н. Психология отношений. Избранные психологические труды. Москва: Воронеж, 1998. $538 \mathrm{c}$.

16. Пантилеев С. Р. Самоотношение как эмоционально-оценочная система. Москва: Изд-во Моск. ун-та, 1991. $100 \mathrm{c}$.

17. Семенов И. Н., Репецкий Ю. А. Личностное самоопределение как ключевой фактор образования взрослых. Мир психологии. 1999. №2. С. 32-38.

18. Столин В. В. Познание себя и отношение к себе в структуре самосознания личности: дис. ...д-ра психол.наук:19.00.01. Москва, 1985. 530 с.

19. Столин В. В. Самосознание личности. Москва: Издательство Московского университета, 1983. 284 с.

20. Чекалина А. А. Профессиональная самореализация женщины. Мир психологии. 2005. №3 (43). C. $127-139$.

21. Wylie R. C. The Self-Concept: Volume 2. Theory and Research on Selected Topics. Lincoln: University of Nebraska Press, 1979. 